\title{
Correction: Invasiveness as a putative additional virulence mechanism of some atypical Enteropathogenic Escherichia coli strains with different uncommon intimin types
} Denise Yamamoto ${ }^{1,2}$, Rodrigo T Hernandes ${ }^{1,2}$, Miguel Blanco ${ }^{3}$, Lilo Greune ${ }^{2}$, M Alexander Schmidt ${ }^{2}$, Sylvia M Carneiro ${ }^{4}$, Ghizlane Dahbi ${ }^{3}$, Jesús E Blanco ${ }^{3}$, Azucena Mora ${ }^{3}$, Jorge Blanco ${ }^{3}$ and Tânia AT Gomes*1

Address: ${ }^{2}$ Universidade Federal de São Paulo (UNIFESP), São Paulo, Brazil, Rua Botucatu, 862, $3^{\circ}$ andar, Vila Clementino, São Paulo, São Paulo, CEP 04023-062, Brazil, 2Institut für Infektiologie, Zentrum für Molekularbiologie der Entzündung, Westfälische Wilhelms-Universität, Münster, Germany, ${ }^{3}$ E. coli Reference Laboratory (LREC), Department of Microbiology and Parasitology, Faculty of Veterinary, University of Santiago de Compostela, Lugo, Spain and ${ }^{4}$ Laboratório de Biologia Celular do Instituto Butantan, São Paulo, Brazil

Email: Denise Yamamoto - dyamamoto@unifesp.br; Rodrigo T Hernandes - hernandes@unifesp.br; Miguel Blanco - miguel.blanco@usc.es; Lilo Greune - lilo@uni-muenster.de; M Alexander Schmidt - infekt@uni-muenster.de; Sylvia M Carneiro - sycarneiro@butantan.gov.br; Ghizlane Dahbi - ghizlane.dahbi@usc.es; Jesús E Blanco - jesuseulogio.blanco@usc.es; Azucena Mora - azucena.mora@usc.es;

Jorge Blanco - jorge.blanco@usc.es; Tânia AT Gomes* - tatg.amaral@unifesp.br

* Corresponding author

Published: II November 2009

BMC Microbiology 2009, 9:235 doi:10.1 I86/147I-2180-9-235
Received: 30 October 2009

Accepted: II November 2009

This article is available from: http://www.biomedcentral.com/l47|-2/80/9/235

(C) 2009 Yamamoto et al; licensee BioMed Central Ltd.

This is an Open Access article distributed under the terms of the Creative Commons Attribution License (http://creativecommons.org/licenses/by/2.0), which permits unrestricted use, distribution, and reproduction in any medium, provided the original work is properly cited.

We lately detected that some important errors were introduced during the production of the last version of our article [1] regarding some Greek letters used to classify intimin subtypes. We regret that these errors were introduced in the final version.

In Table 1, the Greek letters used to nominate intimin subtype omicron should be corrected (o instead of $\mu$ ). Furthermore, intimin upsilon (Greek letter- $v$ ) appears with a wrong symbol $(v)$. Please, find below the corrected version of Table 1.

In "Results and Discussion" (Page 3, Paragraph 1) and in "Methods" ("Typing of intimin genes", Page 8), intimin upsilon (Greek letter- $v$ ) appears again with a wrong symbol $(v)$.

Table I: Characteristics of the aEPEC strains studied.

\begin{tabular}{|c|c|c|c|c|c|}
\hline \multirow[t]{2}{*}{ Strain } & \multirow[t]{2}{*}{ Serotype } & \multirow[t]{2}{*}{ Intimin Type } & \multirow[t]{2}{*}{ Adherence pattern } & \multicolumn{2}{|l|}{ FAS test } \\
\hline & & & & HeLa cells & T84 cells \\
\hline $0621-6$ & ONT:H- & $\sigma^{*}$ & LA & + & + \\
\hline$|55|-2$ & ONT:H- & o & LA & + & + \\
\hline 1632-7 & $\mathrm{O} 26: \mathrm{H}^{-}$ & $u^{* *}$ & DA & + & + \\
\hline$|87|-\mid$ & $\mathrm{O} 34: \mathrm{H}^{-}$ & $\theta 2 * *$ & LAL & + & + \\
\hline $405 I-6$ & O104:H2 & o & AA & + & + \\
\hline $428 I-7$ & O104: $\mathrm{H}^{-}$ & $\tau * *$ & LAL & + & + \\
\hline$E 2348 / 69$ & OI27:H6 & $\alpha l$ & LA & + & + \\
\hline
\end{tabular}




\section{References}

I. Yamamoto D, Hernandes RT, Blanco M, Greune L, Schmidt MA, Carneiro SM, Dahbi G, Blanco JE, Mora A, Blanco J, Gomes TA: Invasiveness as a putative additional virulence mechanism of some atypical Enteropathogenic Escherichia coli strains with different uncommon intimin types. BMC Microbiology 2009, 9:146.

Publish with Bio Med Central and every scientist can read your work free of charge

"BioMed Central will be the most significant development for disseminating the results of biomedical research in our lifetime." Sir Paul Nurse, Cancer Research UK

Your research papers will be:

- available free of charge to the entire biomedical community

- peer reviewed and published immediately upon acceptance

- cited in PubMed and archived on PubMed Central

- yours - you keep the copyright

Submit your manuscript here:

http://www.biomedcentral.com/info/publishing_adv.asp 